\title{
Meningkatkan kualitas hidup sehat masyarakat Dayak melalui lokakarya Sekolah Sehat di Kabupaten Landak Kalimantan Barat
}

\author{
Rizki Hegia Sampurna \\ Program Studi Ilmu Administrasi Publik, Universitas Muhammadiyah Sukabumi, \\ Indonesia
}

\section{rizkicdn@gmail.com}

\begin{abstract}
The Indonesian government continues to strive to implement the health promoting school program nationwidely. Yet the disparity in its implementation is still high. Most schools in remote areas have not been able to implement it. Such as Sekolah Dasar Negeri 08 Berinang Mayun and Sekolah Dasar Negeri 02 Sidan which are located in the middle of palm oil plantations in Landak, West Kalimantan. Students of and communities around the two schools are Dayak people whose health quality are still poor. Based on that, we conducted a healthpromoting school workshop at the two schools. The workshop was carried through lectures, focus group discussions, and simulations. In the end, the participants were required to produce a health promoting school plan as an outcome. A number of indicators such as KWL analysis, participants' feedback and pre-post test analysis showed that there is an increase in the knowledge and skills of participants regarding the health promoting school program. But the most obvious achievement is that participants have designed a health-promoting school plan that they will carry out in their respective schools.
\end{abstract}

Abstrak Pemerintah Indonesia terus berupaya melaksanakan program Sekolah
Sehat secara nasional. Namun disparitas dalam implementasinya masih tinggi.
Sebagian besar sekolah di daerah terpencil belum mampu melaksanakannya.
Seperti Sekolah Dasar Negeri 08 Berinang Mayun dan Sekolah Dasar Negeri 02
Sidan yang terletak di tengah-tengah perkebunan kelapa sawit di Landak,
Kalimantan Barat. Siswa dan masyarakat sekitar kedua sekolah tersebut adalah
masyarakat Dayak yang kualitas kesehatannya masih buruk. Atas dasar itu, kami
mengadakan lokakarya Sekolah Sehat di kedua sekolah tersebut. Workshop
dilakukan melalui ceramah, focus group discussion, dan simulasi. Pada akhirnya,
peserta diharuskan membuat rencana sekolah yang mempromosikan kesehatan
sebagai luaran. Sejumlah indikator seperti analisis KWL, tanggapan peserta, dan
analisis pre-post test menunjukkan adanya peningkatan pengetahuan dan
keterampilan peserta tentang program sekolah bina kesehatan. Namun
pencapaian yang paling nyata adalah peserta telah merancang rencana Sekolah
Sehat yang akan mereka laksanakan di sekolah masing-masing.

Keywords: health promoting school; health quality; Dayak people; workshop

\section{$\partial$ OPEN ACCESS}

Citation: Sampurna, R.H. (2020). Meningkatkan kualitas hidup sehat masyarakat Dayak melalui lokakarya Sekolah Sehat di Kabupaten Landak Kalimantan Barat. Riau Journal of Empowerment, 3(2), 117-126. https://doi.org/10.31258/raje.3.2.117-126

Paper type: Community service

Received: 2020-04-07 Revised: 2020-08-05 Accepted: 2020-08-08

Language: Bahasa Indonesia (id) ISSN 2623-1549 (online), 2654-4520 (print)

(C) 2020 Rizki Hegia Sampurna. Author(s) retain the copyright of article published in this journal, with first publication rights granted to Riau Journal of Empowerment. The article is licenced under $\underline{\text { Creative Commons Attribution } 4.0}$ International License. This license permits unrestricted use, distribution, and reproduction in any medium, provided the original author and source are credited. 


\section{PENDAHULUAN}

Program Sekolah Sehat merupakan salah satu program strategis yang digulirkan oleh World Health Organization (WHO) pada tahun 1995 dengan tujuan untuk memobilisasi dan meningkatkan kampanye dan pendidikan kesehatan baik pada tingkat lokal, regional, nasional maupun global. Sekolah Sehat atau dikenal dengan istilah 'health promoting school' adalah sekolah yang secara konstan memperkuat kapasitasnya sebagai lingkungan yang sehat untuk hidup, belajar dan bekerja (World Health Organization, 2020). Menurut Piagam Ottawa, ada enam komponen utama Sekolah Sehat, yaitu: (1) kebijakan Sekolah Sehat, (2) lingkungan fisik sekolah, (3) lingkungan sosial sekolah, (4) keterampilan kesehatan individu dan kompetensi aksi, (5) jaringan/keterlibatan masyarakat/komunitas, dan (6) layanan kesehatan (International Union for Health Promotion and Education, 2009).

Merespon hal itu, pemerintah Indonesia mengeluarkan sejumlah kebijakan sebagai upaya mempromosikan dan meningkatkan kesehatan anak usia sekolah, salah satunya dengan program "Sekolah Sehat." Dalam pelaksanaannya, Menteri Kesehatan mengeluarkan Keputusan Menteri Kesehatan RI No. 1429 tahun 2006 tentang pedoman penyelenggaraan kesehatan lingkungan sekolah. Selain itu, sejumlah petunjuk teknis dan pedoman pelaksanaan dan model Sekolah Sehat juga dikeluarkan masing-masing oleh Kementerian Kesehatan tahun 2018 dan Kementerian pendidikan dan Kebudayaan tahun 2009 dan 2012.

Dalam perkembangannya, pemerintah kemudian merancang ulang model sekolah sehat yang sesuai dengan jati diri bangsa Indonesia. Yaitu dengan memasukkan nilai-nilai utama karakter bangsa. Sehingga lahirlah konsep Sekolah Sehat berkarakter (SSB) yang didefinisikan sebagai sekolah yang membangun peserta didik sebagai insan sehat dan mengembangkan potensi psikososialnya yang mencerminkan nilai religius, nasionalis, mandiri, gotong royong, dan integritas (Arianto et al., 2019). Sehingga sasarannya tidak hanya pada pengembangan kesehatan aspek fisik, tetapi juga non fisik dan personal (Arianto et al., 2019).

Namun dalam pelaksanaannya, program Sekolah sehat ini belum berjalan secara merata di seluruh pelosok tanah air, khususnya di daerah pelosok dan pedalaman. Misalnya adalah sekolah- sekolah di pedalaman atau daerah perkebunan sawit di Kalimantan Barat (Kalbar). Meskipun program Sekolah Sehat sudah menjadi salah satu program prioritas dan unggulan Pemerintah Provinsi (Pemprov) Kalbar. Hal itu dibuktikan dengan sejumlah kebijakan sebagai upaya mendorong Sekolah Sehat serta keberhasilan Pemprov Kalbar membawa salah satu sekolah di wilahnya menjadi juara pertama Lomba Sekolah Sehat (LSS) tingkat nasional pada tahun 2019 (Joewono, 2019). Namun, sejumlah sekolah yang berada di pedalaman dan di tengah perkebunan sawit masih jauh dari standar hidup sehat. Seperti sekolah-sekolah yang berada di tengah perkebunan sawit di Kecamatan Menyuke Kabupaten Landak.

Kesenjangan implementasi program Sekolah Sehat antar sekolah di daerah ini sangat wajar. Mengingat sejumlah unsur penopang Sekolah Sehat tidak dimiliki oleh semua sekolah, khususnya untuk sekolah-sekolah di daerah pelosok dan pedalaman. Kalau merujuk pada sejumlah pedoman diatas, pengembangan Seolah Sehat ini meliputi beberapa standar yang belum tentu dimiliki semua sekolah seperti standar fisik, saran prasarana, standar ketenagaan, dan lain-lain. Besar kemungkinan sarana yang dimiliki oleh sekolah di pelosok dan pedalaman tidak memenuhi standar Sekolah Sehat. Sejumlah studi tentang evaluasi program Sekolah Sehat menunjukkan bahwa ketersediaan anggaran dan saran sangat menentukan (Hermiyanty et al., 2016; Zubaidah et al., 2017; Quintina et al., 2018). Apalagi terkait ketenagaan, misalnya 
tidak semua pendidik memiliki pengetahuan dan kemampuan yang memadai dalam melaksanakan program Sekolah Sehat di sekolahnya. Dalam kaitan inilah, peran berbagai pihak termasuk akademisi sangat dibutuhkan untuk meningkatkan kapasitas ketenagaan.

Dalam konteks itulah, kegiatan lokakarya ini diadakan di sekolah-sekolah yang berada di tengah perkebunan sawit di Kecamatan Menyuke Kabupaten Landak, Kalimantan Barat. Yaitu Sekolah Dasar Negeri 08 Berinang Mayun dan Sekolah Dasar Negeri 02 Sidan. Kabupaten Landak sendiri merupakan salah satu daerah hasil pemekaran Kabupaten Mempawah tahun 1999. Ibu Kota kabupaten ini terletak di Ngabang. Memiliki luas wilayah $9.909,10 \mathrm{~km}^{2}$ dan berpenduduk sebesar 282.026 jiwa (https://landakkab.go.id). Kedua sekolah tersebut berada di tengah perkebunan sawit yang dimiliki sejumlah perusahaan seperti PT. Sampoerna Agro. Dari daerah perkotaan Landak, masih memerlukan waktu 2 jam untuk sampai ke lokasi sekolah. Mayoritas warga sekitar yang merupakan orang tua murid adalah petani atau buruh di perkebunan tersebut. Akses jalan menuju ke kedua sekolah itu masih berupa jalan tanah. Sehingga disaat hujan sangat berlumpur dan sulit untuk dilalui kendaraan. Jalan itu pun sebetulnya milik perusahaan perkebunan yang dibangun untuk truk-truk pengangkut sawit. Sampai saat ini sarana listrik dan air bersih masih sulit. Sekalipun ada masih berupa sumbangan dari pihak perusahaan perkebunan atau swadaya masyarakat. Jadi masih sangat terbatas. Tidak mengherankan jika pola dan kualitas hidup sehat masyarakat sekitar dan khususnya anak usia sekolah masih jauh dari layak. Sehingga penyelenggaraan program Sekolah Sehat sangat dibutuhkan sebagai salah satu upaya untuk menjawab permasalahan tersebut.

Atas dasar itu, kegiatan lokakarya "Sekolah Sehat" diadakan di kedua sekolah sasaran tersebut. Tujuan utamanya diantaranya: (1) untuk meningkatkan kualitas hidup sehat siswa dan warga sekitar sekolah yang mayoritas masyarakat Dayak, (2) menanamkan budaya hidup sehat sejak dini kepada siswa, (3) meningkatkan pengetahuan dan kapasitas pendidik di kedua sekolah tersebut terkait pendidikan kesehatan melalui program Sekolah Sehat. Namun yang lebih spesifik, target luaran dari lokakarya ini adalah kemampuan para pendidik untuk membuat dan menerapkan rencana dan rancangan program Sekolah Sehat yang dirumuskan oleh mereka.

\section{METODE PENERAPAN}

\section{Sekolah Sasaran}

Kegiatan lokakarya ini merupakan bagian dari program Corporate Social Responsibility (CSR) PT. Sampoerna Agro. Adapun sekolah sasarannya adalah Sekolah Dasar Negeri 08 Berinang Mayun dan Sekolah Dasar Negeri 02 Sidan. Kedua sekolah tersebut berada di Kecamatan Menyuke, Kabupaten Landak, Kalimantan Barat yang merupakan wilayah terdekat dengan perkebunan sawit milik PT. Sampoerna Agro. Adapun tujuannya adalah untuk menuju Sekolah Sehat dimana melalui pengembangan program-program sekolah berbasis Sekolah Sehat dan peningkatan kapasitas dan profesionalisme guru serta manajemen sekolah diharapkan dapat meningkatkan tarap hidup sehat masyarakat sekitar yang mayoritas Dayak. Selain itu, juga agar menjadi acuan bagi pengembangan sekolah sehat bagi sekolah-sekolah lain disekitarnya. 


\section{Peserta dan Jadwal Kegiatan}

Adapun peserta kegiatan Lokakarya Sekolah Sehat ini adalah kepala sekolah dan sebagian besar guru kedua sekolah tersebut yang berjumlah 13 peserta dari total 16 orang yang diundang. 3 orang guru tidak dapat mengikuti lokakarya, dikarenakan 2 orang ada kegiatan lain dan 1 orang sakit.

Kegiatan lokakarya ini dilaksanakan pada tanggal 12-15 November 2019 dipusatkan di Sekolah Dasar Negeri 08 Berinang Mayun. Namun demikian, kunjungan dan identifikasi lingkungan juga dilakukan ke Sekolah Dasar Negeri 02 Sidan. Sedangkan rundown kegiatan lokakarya ini dapat dilihat pada Tabel 1 .

Tabel 1. Rundown kegiatan lokakarya

\begin{tabular}{|c|c|c|}
\hline No & Waktu & Kegiatan \\
\hline 1 & $12-11-2019$ & $\begin{array}{l}\text { - Menyiapkan rencana dan rancangan kegiatan pelatihan disesuaikan } \\
\text { dengan kondisi sekolah sasaran } \\
\text { - Orientasi dan perkenalan } \\
\text { - Identifikasi pengetahuan dasar dan kebutuhan pesrta terkait } \\
\text { - } \text { program sekolah sehat melalui KWL } \\
\text { - } \\
\text { - Menilian baseline pengetahuan peserta melalui pre-test } \\
\text { - }\end{array}$ \\
\hline 2 & $13-11-2019$ & $\begin{array}{l}\text { - Penyampaian materi terkait program Sekolah Sehat, Trias UKS dan } \\
\text { integrasi program Sekolah Sehat kedalam kurikulum dan RPP }\end{array}$ \\
\hline 3 & $14-11-2019$ & $\begin{array}{l}\text { - Membuat rencana dan rancangan Sekolah Sehat melalui diskusi } \\
\text { kelompok (FGD) } \\
\text { - Pemaparan dan Penguatan rencana dan rancangan sekolah sehat } \\
\text { oleh masing-masing kelompok }\end{array}$ \\
\hline 4 & $15-11-2019$ & $\begin{array}{l}\text { - Identifikasi kondisi akhir peserta melalui KWL } \\
\text { - Assessment ketercapaian melalui post-test }\end{array}$ \\
\hline
\end{tabular}

\section{Penilaian Ketercapaian (Assessment)}

Untuk mengukur tingkat ketercapaian kegiatan lokakarya tentang program Sekolah Sehat ini, penulis menggunakan bebrapa metode. Pertama, menggunakan analisis sederhana yaitu $K-$ What I Know, W- What I Want to Know, dan L - What I Learned yang populer dikenal sebagai KWL. Tujuan utama metode ini adalah untuk menjaring aspirasi peserta dan mengidentifikasi kebutuhan mereka terkait materi lokakarya. Selain tentunya untuk identifikasi pengetahuan baseline dan pasca lokakarya. Metode KWL ini lebih bersifat deskriptif. Kedua, menggunakan analisis pre-post test. Analisis ini jelas ditujukan untuk mengukur tingkat perubahan pengetahuan peserta pra dan pasca lokakarya dengan analisis kuantitatif sederhana. Ketiga, menggunakan analisa target luaran dari kegiatan lokakarya ini. Yaitu peserta setidaknya dapat membuat rancangan penerapan program Sekolah Sehat di sekolah mereka. Metode penilaian ini lebih bersifat kualitatif dan menurut hemat penulis justru lebih akurat menggambarkan ketercapaian dari lokakarya ini. Karena memang lokakarya ini selain didesain sebagai pembelajaran kognitif, juga berorientasi pada luaran yang sifatnya praktis atau implementatif. 


\section{Pelatihan Program Sekolah Sehat}

Materi utama yang disampaikan pada peserta lokakarya ini adalah terkait (1) pengembangan rancangan sekolah sehat yang pendekatan berbasis dari sekolah dan memfokuskan pada empat strategi, yaitu Pemotivasian (intervensi), Pembiasaan (habituasi), Peneladanan (tokoh model), dan Konsistensi (Arianto et al., 2019), (2) penguatan tiga komponen usaha kesehatan sekolah atau lebih dikenal sebagai Trias UKS. Khusus terkait Trias UKS, tiap komponen diidentifikasi aspek-aspek pentingnya seperti fokus program, target capaian, dan kegiatan. Dan yang tidak kalah pentingnya penjajakan kerjasama dengan sejumlah pihak yang berkepentingan (Widyaningrum et al., 2016). Mengingat peran UKS dalam meningkatkan kualitas hidup sehat anak sekolah (Prasetyo et al., 2014). Dalam sesi ini, materi disampaikan baik melalui metode interaktif seperti ceramah, melalui media video, diskusi dan simulasi (Gambar 1).

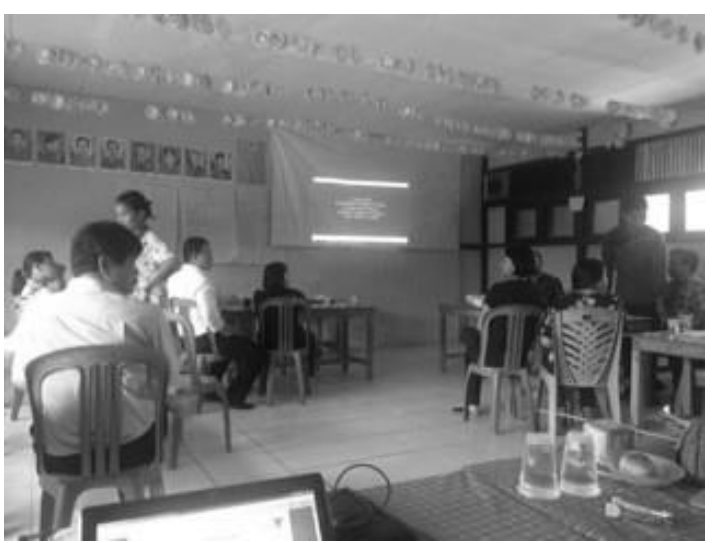

(a)

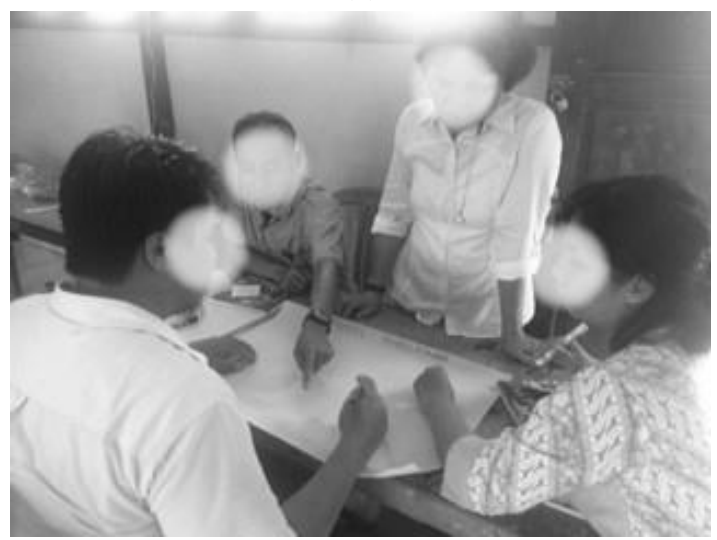

(c)

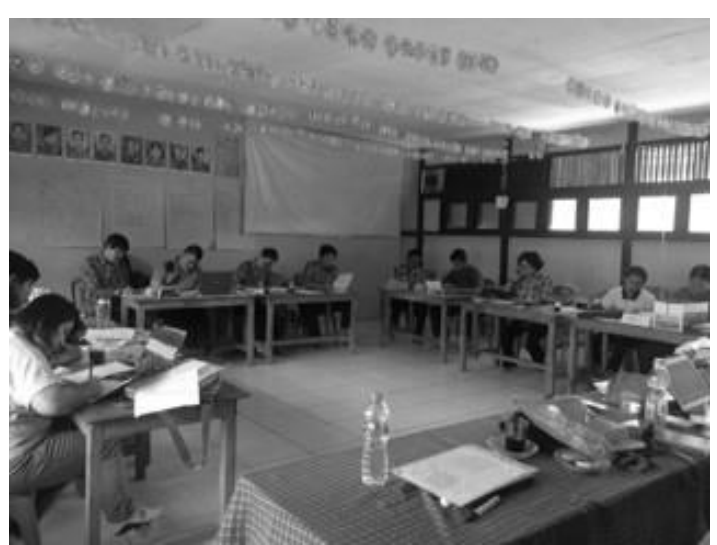

(b)

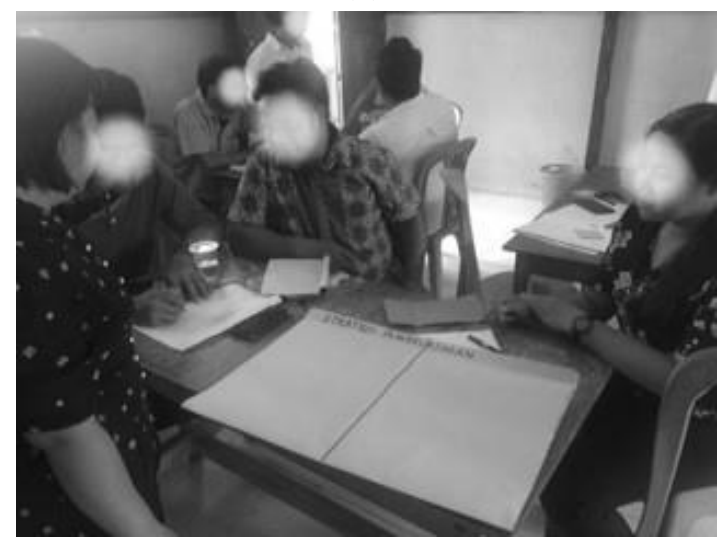

(d)

Gambar 1. Penyampaian materi melalui video (a), suasana pre-test (b), dan diskusi kelompok (c, d)

Setelah penyampaian materi tersebut, peserta kemudian diarahkan untuk membuat kelompok untuk mengidentifikasi kegiatan-kegiatan sekolah yang sudah ada atau yang direncanakan untuk dimasukkan ke dalam program Sekolah Sehat. Selain penguatan aspek kelembagaan seperti identifikasi penanggungjawab beserta tupoksinya yang jelas, program Sekolah Sehat yang mereka rancang juga diarahkan pada pada penguatan aspek perilaku siswa (Sari, 2013). Karena aspek perilaku hidup sehat merupakan indikator utama keberhasilan program Sekolah Sehat (Susanto et al., 2016; Yufiarti et al., 2019). Nampak sekali peserta sangat antusias mengikuti kegiatan ini. Hal ini mungkin disebabkan oleh dua sebab. Pertama, karena program Sekolah Sehat sebetulnya mudah untuk dipahami dan sebagian kegiatan 
embriotiknya sudah ada di sekolah masing-masing. Kedua, karena desain lokakarya ini lebih bersifat partisipatif dan interaktif. Materi disampaikan lebih banyak menggunakan metode diskusi, brain-storming dan simulasi. Karena metode-metode tersebut terbukti lebih efektif (Suprayekti \& Anggraeni, 2017).

\section{Rancangan Penerapan Program Sekolah Sehat}

Pada sesi atau hari ke-3, kegiatan lokakarya difokuskan pada pembuatan rencana dan rancangan sekolah Sehat. Dalam sesi ini peserta diarahkan untuk melakukan diskusi kelompok/Focus Group Discussion (FGD) dan membuat rencana dan rancangan Sekolah Sehat. Setelah itu, setiap kelompok diminta untuk mempresentasikan hasilnya dan kelompok lain memberikan saran dan masukan. Sebagai contoh, Tabel 2 menampilkan rencana dan rancangan program Sekolah Sehat Sekolah Dasar Negeri 08 Berinang Mayun sebagai hasil FGD peserta.

Tabel 2. Program kerja sekolah sehat Sekolah Dasar Negeri 08 Berinang Mayun Semester Ganjil Tahun Pelajaran 2019/2020

\begin{tabular}{|c|c|c|c|c|}
\hline No & Nama Kegiatan & $\begin{array}{c}\text { Waktu } \\
\text { pelaksanaan }\end{array}$ & Penanggungjawab & Output \\
\hline 1 & $\begin{array}{l}\text { Kebersihaan Diri Pribadi } \\
\text { - Pemeriksaan kuku, } \\
\text { telinga, mulut, rambut, } \\
\text { dan lain-lain } \\
\text { - Cuci tangan }\end{array}$ & Setiap minggu & Wali kelas & $\begin{array}{l}\text { Siswa terbiasa } \\
\text { menjaga } \\
\text { kebersihan diri } \\
\text { pribadi seperti } \\
\text { tangan, kuku, } \\
\text { rambut, dan lain- } \\
\text { lain. }\end{array}$ \\
\hline 2 & $\begin{array}{l}\text { Lingkungan Kelas: } \\
\text { - Piket kelas }\end{array}$ & Setiap hari & Wali kelas & $\begin{array}{l}\text { Terciptanya } \\
\text { ruangan kelas } \\
\text { yang bersih, rapi } \\
\text { dan nyaman. }\end{array}$ \\
\hline 3 & $\begin{array}{l}\text { Lingkungan Sekolah Secara } \\
\text { Umum: } \\
\text { - LiSA } \\
\text { - TOGA } \\
\text { - Sanitasi } \\
\text { - Panel surya }\end{array}$ & Setiap minggu & $\begin{array}{l}\text { Yuliana } \\
\text { Jongnam } \\
\text { Renald Aldi Cuok }\end{array}$ & $\begin{array}{l}\text { Terciptanya } \\
\text { lingkungan yang } \\
\text { hijau dan asri. } \\
\text { Tersedia dan } \\
\text { terawatnya sarana } \\
\text { dan prasarana. }\end{array}$ \\
\hline 4 & $\begin{array}{l}\text { Lingkungan Warga Sekitar } \\
\text { - Kampanye cuci tangan } \\
\text { - Pemberian obat cacing }\end{array}$ & Tiap semester & $\begin{array}{l}\text { KS, dewan guru, } \\
\text { Puskesmas dan } \\
\text { Komite sekolah }\end{array}$ & $\begin{array}{l}\text { Terciptanya } \\
\text { lingkungan warga } \\
\text { sekitar yang sehat, } \\
\text { membudayakan } \\
\text { gaya hidup sehat }\end{array}$ \\
\hline
\end{tabular}

Dari Tabel 2, penulis dapat menyimpulkan bahwa sebetulnya mayoritas peserta dapat membuat rencana dan rancangan Sekolah Sehat yang sesuai dengan kondisi sekolah mereka. Pihak sekolah dalam hal ini kepala sekolah dan guru dapat mengidentifikasi prioritas masalah kesehatan yang dihadapi peserta didiknya serta masyarakat sekitar. Sehingga program atau kegiatan Sekolah Sehat yang mereka rencanakan juga relevan dan ditujukan untuk menjawab masalah tersebut.

Menurut penuturan mayoritas peserta, sebetulnya sebagian dari kegiatan yang mereka canangkan itu sudah dikerjakan di sekolah mereka masing-masing. Namun masih bersifat 
sporadik dan tidak berkesinambungan. Hal itu disebabkan oleh beberapa kendala. Pertama, beberapa kegiatan seperti sanitasi memerlukan fasilitas yang memadai seperti sumur bor yang sebelumnya belum ada. Namun saat lokakarya diadakan fasilitas itu sudah disediakan oleh pihak PT. Sampoerna Agro. Kedua, belum adanya pemahaman yang utuh diantara warga sekolah khususnya guru terkait program Sekolah Sehat ini. Ketiga, tidak adanya koordinator atau penanggungjawab yang tetap dan kompeten dari kegiatan itu. Sebelum lokakarya ini diadakan sebagian guru merasa tidak percaya diri kalau mereka mampu menjalankan tugas sebagai penananggungjawab kegiatan. Atau lebih tepatnya, penulis menduga adanya saling tunjuk antar sesama mereka. Keempat, belum adanya komunikasi yang intensif dan khususnya kerjasama dengan pihak luar seperti Puskesmas setempat dalam menyelenggarakan program Sekolah Sehat ini.

\section{Penilaian Ketercapaian Sasaran (Assessment)}

Untuk mengukur tingkat ketercapaian tujuan lokakarya ini dilakukan dua metode penilaian. Pertama, metode pre dan post-test analisis. Gambar 2 menampilkan hasil dari analisis pre dan post-test.

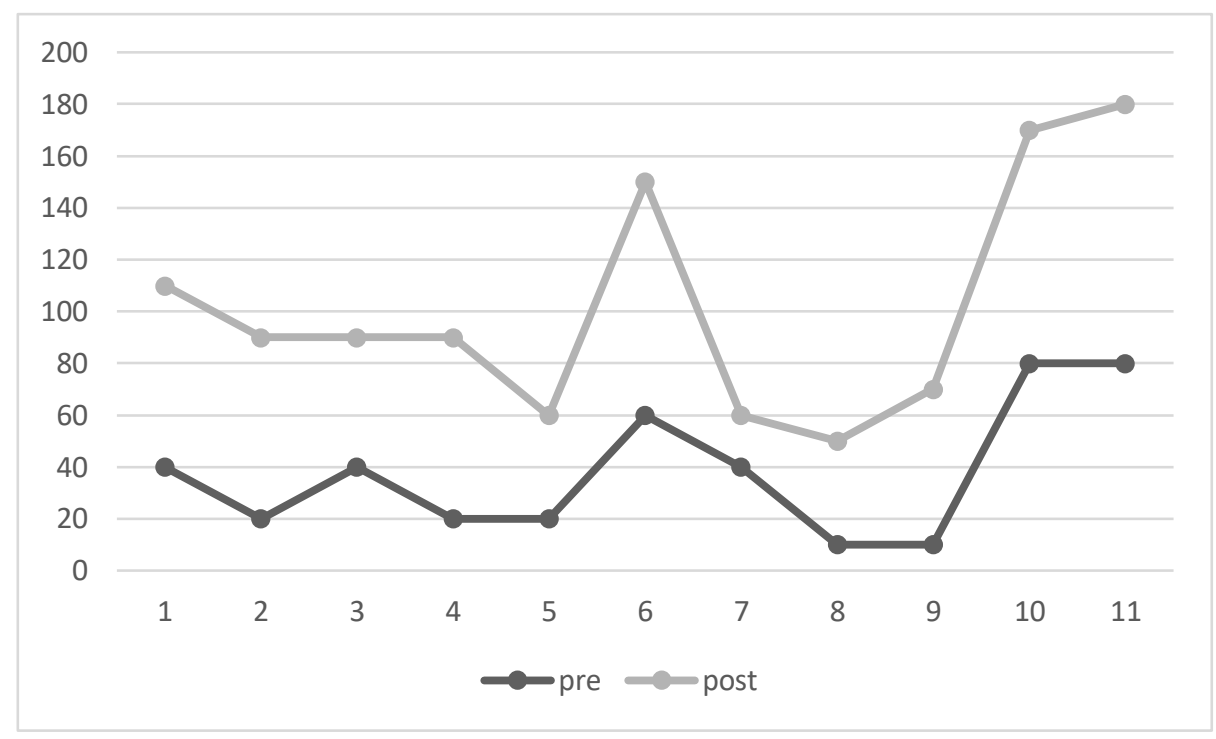

Gambar 2. Hasil pre-post test pelatihan

Peserta yang mengikuti pre-post test berjumlah 11 orang. Sedangkan 2 orang lainnya ada yang tidak mengikuti pre atau post test. Sehingga tidak dimasukkan dalam analisis. Dengan mengamati Gambar 2, kita dapat mengetahui informasi sebagai berikut : (1) Nilai terkecil yang diperoleh peserta di saat pre-test adalah 10, sedangkan post test adalah 20.; (2) Nilai terbesar yang diperoleh peserta di saat pre-test adalah 80, sedangkan post test adalah 100; (3) Selisih nilai terbesar dan terkecil di saat pre-test adalah 70, sedangkan post-test adalah 80; (4) Ratarata presentasi jawaban benar disaat pre-test adalah 38,5\% sedangkan post-test adalah 56,2\%, sehingga diperoleh selisih $17,7 \%$. Data itu menunjukkan beberapa poin penting. Pertama, adanya selisih kompetensi cukup besar antar peserta. Kedua, selisih itu tidak berubah baik pada pre-test maupun post-test. Meskipun ada kenaikan nilai pada tiap peserta. Artinya daya serap dari peserta terhadap materi lokakarya tidak merata. Ketiga, selisih nilai antara pre-test dan post-test hanya 17, 7\%. Artinya tingkat keberhasilan dari lokakarya ini kurang signifikan. Namun demikian, hal itu tidak terlalu mengejutkan. Karena disebabkan beberapa faktor. Salah 
satunya karena soal pre/post-test seluruhnya bersifat kognitif. Sedangkan materi dari lokakarya juga banyak bermuatan keterampilan terapan yang berbasis kelompok.

Kedua, metode KWL. Selain untuk mengukur tingkat perubahan pengetahuan peserta, metode ini ditujukan untuk menjaring dan mengidentifikasi kebutuhan peserta terkait topik atau materi lokakarya. Sehingga kegiatan lokakarya ini lebih tepat sasaran. Perhatikan Tabel 3 yang merupakan hasil dari metode KWL.

Tabel 3. Pemetaan KWL peserta terkait sekolah sehat

\begin{tabular}{llll}
\hline K - What I Know & W - What I Want to Know & L - What I Learned \\
\hline - Pengertian program & - Sekolah Adiwiyata & - Cuci tangan \\
sekolah sehat & - Tanaman Obat Keluarga & - Pendidikan kesehatan \\
- Pojok baca & (TOGA) & - Lingkungan sehat, \\
- Lingkungan bersih, & - Meningkatkan kualitas & layanan kesehatan, \\
ramah dan nyaman & sekolah tertinggal dengan & pendidikan kesehatan \\
- Anak aktif dalam & cara kerjasama dengan & - 3 pilar UKS/ Trias UKS \\
pembelajaran & sekolah yang maju & - Pembinaan lingkungan \\
- Ramah anak, sehat dan & Meningkatkan & sehat \\
rapi & kompetensi guru & - Menyusun program kerja \\
- Seminar orang tua & Keberlanjutan program & sekolah sehat \\
- Cuci tangan & sekolah sehat yang & - Sekolah sehat \\
- Air bersih & sedang dibina & - Memasukkan program \\
- Penerangan sekolah/kelas & Menerapkan sekolah & sekolah sehat ke dalam \\
- kerjasama & sehat kepada masyarakat & RPP \\
& sekitar & Ruang UKS \\
\hline
\end{tabular}

Hasil pemetaan KWL pada Tabel 3, menunjukkan beberapa hal penting. Pertama, ada disparitas kompetensi dan kebutuhan diantara peserta. Hal ini menguatkan analisis pre dan post-test diatas. Sehingga timbul overlap/tumpang tindih yang cukup signifikan antar materi KWL. Kedua, menunjukkan pentingnya pendekatan diskusi, kerja kelompok, penularan, dan lain-lain dalam kegiatan lokakarya sehingga sebaran manfaat dari kegiatan lebih luas. Peningkatan kompetensi yang relatif merata di kalangan guru sangat berperan. Sejumlah studi menunjukkan bahwa tumbuhnya budaya dan perilaku hidup sehat di kalangan anak usia sekolah sangat dipengaruhi oleh guru dan lingkungan sekolah (Irwandi, 2016; Taryatman, 2016; Kusuma et al., 2019).

\section{KESIMPULAN}

Kegiatan lokakarya Program Sekolah Sehat mendapatkan respon positif semua peserta yang hadir. Indikator kualitatifnya adalah mulai tumbuhnya tingkat kepercayaan diri peserta, adanya pertumbuhan wawasan, pemahaman dan kemampuan untuk merancang dan melaksanakan program tersebut. Hal itu nampak dari antusiasme peserta selama kegiatan lokakarya berlangsung. Selain itu, analisis KWL juga menunjukkan hal yang sama, ada perubahan positif pengetahuan dan pemahaman. Sedangkan indikator yang menunjukkan adanya pertumbuhan keterampilan adalah hasil kerja peserta baik berupa rancangan Trias UKS maupun program Sekolah Sehat untuk sekolah mereka masing-masing. Selain itu, feedback dan masukan dari peserta juga menunjukkan antusiasme mereka untuk dapat mengikuti kegiatan serupa kedepannya. Secara kuantitatif, hasil pre-post test peserta sekalipun menunjukkan selisih yang 
tidak besar, tetap menunjukkan adanya perubahan dari baseline pengetahuan pra dan pasca kegiatan.

Hal tersebut diatas, meyakinkan kita untuk mengambil kesimpulan bahwa kegiatan lokakarya ini dapat dikatakan sukses. Seperti dikemukakan pada pendahuluan bahwa tujuan lokakarya ini adalah (1) untuk meningkatkan kualitas hidup sehat siswa dan warga sekitar sekolah yang mayoritas masyarakat Dayak, (2) menanamkan budaya hidup sehat sejak dini kepada siswa, (3) meningkatkan pengetahuan dan kapasitas pendidik di kedua sekolah tersebut terkait pendidikan kesehatan melalui program Sekolah Sehat. Meskipun saat ini kita belum dapat mengukur dampak langsung ataupun tidak langsung dari lokakarya ini terhadap peningkatan kualitas hidup sehat siswa dan masyarakat Dayak sekitar. Begitu juga terkait penanaman budaya dan pola hidup sehat siswa. Namun setidaknya sebagian dari tujuan dari kegiatan ini tercapai, yaitu meningkatkan pengetahuan dan kapasitas pendidik di kedua sekolah tersebut terkait pendidikan kesehatan melalui program Sekolah Sehat. Dengan harapan ketercapaian pada tujuan ke-3 ini menjadi modal dasar untuk mencapai dua tujuan yang lain.

Kegiatan lokakarya berjalan lancar dan baik. Peserta sangat mendukung dan antusias dalam kegiatan ini. Namun ada sejumlah kendala (mungkin lebih tepatnya tantangan) yang kita hadapi. Pertama, akses jalan ke lokasi yang menantang. Jalan tanah basah yang cukup menghabiskan energi selama perjalanan. Dari penginapan masih menghabiskan waktu dua jam. Sehingga ketika sampai di lokasi, energi sudah cukup terpakai. Kedua, minimnya sarana atau fasilitas Kegiatan Belajar Mengajar (KBM) atau lokakarya. Sebagian besar materi disampaikan menggunakan alat tulis biasa. LCD projector hanya dapat digunakan sekali, untuk memutar video. Sisanya kegiatan dilakukan secara manual. Saran kami kepada sivitas akademika, untuk dapat melakukan kegiatan pengabdian serupa di daerah-daerah pelosok dan pedalaman.

\section{UCAPAN TERIMA KASIH}

Penulis ingin menyampaikan rasa terima kasih kepada tim Putera Sampoerna Foundation School Development Outreach (PSF-SDO) yang telah memberikan kesempatan kepada penulis untuk berpartisipasi dalam kegiatan pemberdayaan masyarakat ini. Khususnya kepada Pak Agus Sampurno sebagai team leader yang telah memberikan banyak ilmu dan pengalamannya tentang pendidikan dan sekolah yang berkualitas.

\section{Daftar Pustaka}

1. Arianto, I., Ajisuksmo, C.R.P., Husen, A., Widiastuti, \& Rusdi. (2019). Pedoman Sekolah Sehat Berkarakter Sekolah Menengah Pertama. Direktorat Jenderal Pendidikan Dasar dan Menengah Kementerian Pendidikan dan Kebudayaan. https://sehatberkarakterdikdasmen.kemdikbud.go.id/static/file/PEDOMAN_SEKOLAH_SEHAT_BERKARAKTER SMP_REVISED.pdf

2. Hermiyanty, Salmawati, L., \& Oktavian, F. (2016). Evaluasi Implementasi Program Sekolah Dasar Bersih dan Sehat Di Kota Palu. Preventif: Jurnal Kesehatan Masyarakat, 7(1), 13-20. http://jurnal.untad.ac.id/jurnal/index.php/Preventif/article/view/5814

3. International Union for Health Promotion and Education. (2009). Achieving Health Promoting Schools: Guidelines for promoting health in schools. https://www.iuhpe.org/images/PUBLICATIONS/THEMATIC/HPS/HPSGuidelines_ENG.pd $\underline{\mathrm{f}}$ 
4. Irwandi, S., Ufatin, N., \& Sultoni. (2016). Peran Sekolah dalam Menumbuhkembangkan Perilaku Hidup Sehat pada Siswa Sekolah Dasar (Studi Multi Situs di SD Negeri 6 Mataram dan SD Negeri 41 Mataram Kota Mataram Nusa Tenggara Barat). Jurnal Pendidikan: Teori, Penelitian, dan Pengembangan, 1(3), 492-498. http://journal.um.ac.id/index.php/jptpp/article/view/6178

5. Joewono, B.N. (2011, November 15). Pemprov Kalbar Dorong Pembentukan Sekolah Sehat. Kompas.

https://edukasi.kompas.com/read/2011/11/15/20093017/pemprov.kalbar.dorong.pembentuka n.sekolah.sehat.

6. Kusuma, A., Pertiwi, W.E., \& Annissa. (2019). Healthy Media Promotion, Knowledge towards Clean and Healthy Life Behavior among Students. Kes Mas: Jurnal Fakultas Kesehatan Masyarakat, 13(2), 70-75. http://journal.uad.ac.id/index.php/KesMas/article/view/11907

7. Prasetyo, Y.B., Hudha, A.M., \& Mayangsari, W.T. (2014). Pelaksanaan Program Usaha Kesehatan Sekolah Dalam Upaya Meningkatkan Derajat Kesehatan Pada Anak Usia Sekolah Dasar di Lombok Timur. Jurnal Kedokteran Yarsi, 22(2), 102-113. http://academicjournal.yarsi.ac.id/index.php/jurnal-fk-yarsi/article/view/306

8. Quintina, I.S., et al., (2018). Pelaksanaan Program Usaha Kesehatan Sekolah Di Wilayah Binaan Puskesmas Dtp Jayagiri Kabupaten Bandung Barat. Medika Kartika: Jurnal Kedokteran dan Kesehatan, 2(1). http://medikakartika.unjani.ac.id/index.php/mk/article/view/33

9. Sari, I.P.T.P. (2013). Pendidikan Kesehatan Sekolah Sebagai Proses Perubahan Perilaku Siswa. Jurnal Pendidikan Jasmani Indonesia, 9(2), 141-147. https://journal.uny.ac.id/index.php/jpji/article/view/3017

10. Suprayekti, \& Anggraeni, S.D. (2017). Pelaksanaan Program Workshop Belajar Efektif Untuk Orang Tua. JIV-Jurnal Ilmiah Visi, 12(2), 129-136. https://doi.org/10.21009/JIV.1202.5

11. Susanto, T., Sulistyorini, L., Wuryaningsih, E.W., \& Bahtiar, S. (2016). School health promotion: A cross-sectional study on Clean and Healthy Living Program Behavior (CHLB) among Islamic Boarding Schools in Indonesia. International Journal of Nursing Sciences, 3(3), 291-298. https://doi.org/10.1016/j.ijnss.2016.08.007

12. Taryatman. (2016). Budaya Hidup Bersih dan Sehat di Sekolah Dasar. Trihayu: Jurnal Pendidikan Ke-SD-an, 3(1), 8-13. https://jurnal.ustjogja.ac.id/index.php/trihayu/article/view/731

13. Widyaningrum, R., Sitaresmi, M.N., \& Lusmilasari, L. (2016). Evaluasi program trias usaha kesehatan sekolah dan perilaku hidup bersih dan sehat di sekolah luar biasa Bantul. Berita Kedokteran Masyarakat, 32(9), 309-316. https://doi.org/10.22146/bkm.8579

14. World Health Organization. (2020, January 20). Health promoting schools. https://www.who.int/health-topics/health-promoting-schools\#tab=tab_1

15. Yufiarti, Edwita, \& Suharti. (2019). Health Promotion Program (JUMSIH); To Enhance Children's Clean and Healthy Living Knowledge. Jurnal Pendidikan Usia Dini, 13(2), 341355. https://doi.org/10.21009/JPUD.132.10

16. Zubaidah, S., Ismanto, B., \& Sulasmono, B.S. (2017). Evaluasi Program Sekolah Sehat di Sekolah Dasar Negeri. Kelola Jurnal Manajemen Pendidikan, 4(1), 72-82. https://doi.org/10.24246/j.jk.2017.v4.i1.p72-82 